\title{
THE EFFECT OF ACUTE ARTERIOVENOUS FISTULA ON RENAL FUNCTIONS ${ }^{1}$
}

\author{
By JAMES G. HILTON, DONALD M. KANTER,2 DAVID R. HAYS, EDWARD H. \\ BOWEN, JAMES R. GOLUB, JOHN H. KEATING, AND \\ RENÉ WÉGRIA \\ (From the Department of Medicine, St. Luke's Hospital, N. Y., N. Y.)
}

(Submitted for publication November 17, 1954 ; accepted January 26, 1955)

Most investigators are agreed that acute and chronic arteriovenous fistulae produce an increase in cardiac output $(1,2)$. Furthermore, a chronic fistula of sufficient size produces an increase of the blood volume $(1,2)$ and, upon closure of such a chronic fistula, a diuresis of sodium and water (3). On the other hand, it has been shown recently that an acute arteriovenous fistula accommodating 20 per cent or more of the original cardiac output increases the cardiac output but leads to a decrease in the blood flow through the normal systemic capillary bed due to vasoconstriction (1). It appeared of interest, therefore, to determine whether the renal vascular bed participates in this vasoconstriction and, if so, whether an acute arteriovenous fistula affects the renal functions in such a manner as to result in sodium and water retention.

\section{METHODS}

Ten adult female dogs were anesthetized by the intravenous administration of 0.47 to 0.57 cc. per kilogram of a 6 per cent solution of sodium pentobarbital. The trachea was cannulated with a $\mathrm{Y}$-shaped glass tube. Segments of the right common carotid and right brachial arteries, right jugular vein, as well as both femoral arteries and veins were dissected free. After the necessary dissection was completed, a multi-eyed catheter was introduced into the urinary bladder. The animal was then given intravenously 5 to $10 \mathrm{mg}$. of heparin per kilogram after which the vessel cannulations and the other necessary procedures were carried out as described below. The mean arterial blood pressure was recorded with a mercury manometer connected to the central end of the left femoral artery. In 3 of the 10 experiments, the cardiac output was measured according to the Fick prin-

1 This work was made possible by grants-in-aid from the New York Heart Association and the American Heart Association. It was presented at the annual meeting of the American Physiological Society in Chicago in 1953.

2 Postgraduate Fellow of the U. S. Public Health Service. ciple before the establishment of the arteriovenous fistula, during its patency and after its closure. The oxygen consumption was determined by measuring and analyzing the expired air collected in a Douglas bag over a 4 to 6 minute period. The arteriovenous oxygen difference was determined from the analysis of arterial and mixed venous bloods. The arterial blood was obtained from the right brachial artery. The mixed venous blood was withdrawn from the right ventricle through a catheter introduced via the right jugular vein into the right ventricle under fluoroscopic control. Glass cannulae were tied in the central end of the right common carotid artery and the central end of the right femoral vein; these two cannulae were connected by a rubber or polyvinyl tube previously filled with isotonic sodium chloride solution and closed by a screw clamp. A similar communication was established between the central end of the right femoral artery and the central end of the left femoral vein. In $\mathbf{5}$ of the 10 experiments, a catheter connected to a water manometer was introduced via the left femoral vein into the inferior vena cava up to the level of the renal veins in order to measure the changes in venous pressure at this site.

Before being anesthetized, the animals were given orally 0.14 to 0.29 grams of sodium chloride per kilogram of weight to insure adequate urinary excretion of sodium and chloride during the experiment. While the operative procedures were being carried out, priming doses of 1.5 grams of creatinine and 0.07 grams of sodium para-aminohippurate dissolved in $30 \mathrm{cc}$. of water were administered intravenously to the animals. Thereafter a sustaining infusion of isotonic sodium chloride solution containing 19 mg. of creatinine and 3.3 to $3.6 \mathrm{mg}$. of sodium paraaminohippurate per cc. was delivered intravenously at the constant rate of $1 \mathrm{cc}$. per minute by a Bowman pump. The amounts of water, sodium, potassium, and chloride excreted were measured and the renal plasma flow (RPF) as well as the glomerular filtration rate (GFR) and the filtration fraction (FF) were determined. The concentrations of sodium and potassium in plasma and urine were measured with an internal standard flame photometer. A modified Volhard titration method (4) was used to quantitate the chloride concentration in plasma and urine. Exogenous creatinine clearance (5) and para-aminohippurate clearance (6) were used to measure GFR and RPF. The oxygen content of the expired air was determined by the Scholander method (7). The method of Van Slyke and Neill (8) was used 
to measure the oxygen content of the arterial and venous blood.

Each clearance period was of 5 to 15 minutes' duration; the blood samples were withdrawn in the middle of each period from the right brachial artery. In each one of the ten experiments, two control clearance periods were observed. The arteriovenous fistulae were then opened to such a degree as to produce an immediate marked decrease of the mean arterial blood pressure. The size of the fistulae was then adjusted by screw clamps so as to allow the mean arterial blood pressure to return to its control level within 3 to 10 minutes in most experiments. During the patency of the fistulae, two clearance periods were observed in all ten experiments. In the first five experiments, the urine collection was begun as soon as the fistulae were opened, and in the last five experiments, 5 to 12 minutes after the opening of the fistulae.
The fistulae were then closed and the urine collected during two more periods. The urine collection was begun immediately after the closure of the fistulae in the first five experiments and 5 to 18 minutes after the closure of the fistulae in the last five experiments. In experiments 8,9 , and 10, the cardiac output was determined during the control period, during the patency of the fistulae, and after the closure of the fistulae. Each cardiac output measurement was made immediately before the corresponding clearance periods.

\section{RESULTS AND DISCUSSION}

The results obtained are summarized in Table I, Figure 1, and Figure 2. When the fistulae were opened, the mean arterial blood pressure fell immediately 14 to $32 \mathrm{~mm}$. of mercury; the average

TABLE I

Summary of the data obtained in all 10 experiments *

\begin{tabular}{|c|c|c|c|c|c|c|c|c|c|c|c|}
\hline $\begin{array}{c}\text { Experi- } \\
\text { ment } \\
\text { number }\end{array}$ & Period & $\underset{c c . / m i x .}{\text { RPF }}$ & $\begin{array}{c}\text { GFR } \\
c c . / m i n .\end{array}$ & FF & $\begin{array}{c}\text { Plasma } \\
\mathrm{Na} \\
m E q . / L\end{array}$ & $\begin{array}{l}\text { Urine } \\
\text { flow } \\
\text { cc./min. }\end{array}$ & $\begin{array}{c}\text { Na } \\
\text { excreted } \\
\mu E q . / \text { min. }\end{array}$ & $\begin{array}{c}\mathrm{Na} \\
\text { filtered } \\
m E q_{.} / m i n .\end{array}$ & $\begin{array}{l}\text { Percentage of } \\
\text { filtered Na } \\
\text { reabsorbed }\end{array}$ & $\begin{array}{l}\text { Venous } \\
\text { pressure } \\
\text { mm. B. }\end{array}$ & $\begin{array}{l}\text { Cardiac } \\
\text { output } \\
\text { L./min. }\end{array}$ \\
\hline 1 & $\begin{array}{l}\text { Control } \\
\text { Fistula } \\
\text { Recovery }\end{array}$ & $\begin{array}{l}186 \\
172 \\
183\end{array}$ & $\begin{array}{l}60 \\
56 \\
58\end{array}$ & $\begin{array}{l}.32 \\
.33 \\
.32\end{array}$ & $\begin{array}{l}150 \\
150 \\
150\end{array}$ & $\begin{array}{l}0.40 \\
0.29 \\
0.58\end{array}$ & $\begin{array}{l}49 \\
27 \\
76\end{array}$ & $\begin{array}{l}9.00 \\
8.40 \\
8.70\end{array}$ & $\begin{array}{l}99.5 \\
99.7 \\
99.1\end{array}$ & & \\
\hline 2 & $\begin{array}{l}\text { Control } \\
\text { Fistula } \\
\text { Recovery }\end{array}$ & $\begin{array}{l}147 \\
127 \\
138\end{array}$ & $\begin{array}{l}50 \\
46 \\
48\end{array}$ & $\begin{array}{l}.34 \\
.36 \\
.35\end{array}$ & $\begin{array}{l}147 \\
146 \\
147\end{array}$ & $\begin{array}{l}0.35 \\
0.28 \\
0.34\end{array}$ & $\begin{array}{r}44 \\
5 \\
29\end{array}$ & $\begin{array}{l}7.35 \\
6.72 \\
7.05\end{array}$ & $\begin{array}{l}99.4 \\
99.9 \\
99.6\end{array}$ & & \\
\hline 3 & $\begin{array}{l}\text { Control } \\
\text { Fistula } \\
\text { Recovery }\end{array}$ & $\begin{array}{l}239 \\
208 \\
228\end{array}$ & $\begin{array}{l}74 \\
74 \\
74\end{array}$ & $\begin{array}{l}.31 \\
.36 \\
.32\end{array}$ & $\begin{array}{l}147 \\
148 \\
149\end{array}$ & $\begin{array}{l}0.48 \\
0.45 \\
0.79\end{array}$ & $\begin{array}{r}72 \\
42 \\
120\end{array}$ & $\begin{array}{l}10.88 \\
10.95 \\
11.03\end{array}$ & $\begin{array}{l}99.3 \\
99.6 \\
98.9\end{array}$ & & \\
\hline 4 & $\begin{array}{l}\text { Control } \\
\text { Fistula } \\
\text { Recovery }\end{array}$ & $\begin{array}{l}200 \\
162 \\
189\end{array}$ & $\begin{array}{l}65 \\
64 \\
63\end{array}$ & $\begin{array}{l}.32 \\
.40 \\
.33\end{array}$ & $\begin{array}{l}150 \\
149 \\
148\end{array}$ & $\begin{array}{l}0.61 \\
0.53 \\
1.32\end{array}$ & $\begin{array}{r}118 \\
48 \\
157\end{array}$ & $\begin{array}{l}9.75 \\
9.54 \\
9.33\end{array}$ & $\begin{array}{l}98.8 \\
99.5 \\
98.3\end{array}$ & & \\
\hline 5 & $\begin{array}{l}\text { Control } \\
\text { Fistula } \\
\text { Recovery }\end{array}$ & $\begin{array}{l}194 \\
158 \\
184\end{array}$ & $\begin{array}{l}65 \\
63 \\
64\end{array}$ & $\begin{array}{l}.34 \\
.40 \\
.35\end{array}$ & $\begin{array}{l}146 \\
147 \\
147\end{array}$ & $\begin{array}{l}1.20 \\
0.97 \\
1.71\end{array}$ & $\begin{array}{l}231 \\
134 \\
234\end{array}$ & $\begin{array}{l}9.49 \\
9.26 \\
9.41\end{array}$ & $\begin{array}{l}97.6 \\
98.6 \\
97.5\end{array}$ & & \\
\hline 6 & $\begin{array}{l}\text { Control } \\
\text { Fistula } \\
\text { Recovery }\end{array}$ & $\begin{array}{l}217 \\
202 \\
222\end{array}$ & $\begin{array}{l}72 \\
70 \\
71\end{array}$ & $\begin{array}{l}.33 \\
.35 \\
.32\end{array}$ & $\begin{array}{l}143 \\
144 \\
144\end{array}$ & $\begin{array}{l}1.03 \\
0.69 \\
1.24\end{array}$ & $\begin{array}{l}68 \\
11 \\
79\end{array}$ & $\begin{array}{l}10.30 \\
10.08 \\
10.22\end{array}$ & $\begin{array}{l}99.4 \\
99.9 \\
99.2\end{array}$ & $\begin{array}{l}42 \\
57 \\
35\end{array}$ & \\
\hline 7 & $\begin{array}{l}\text { Control } \\
\text { Fistula } \\
\text { Recovery }\end{array}$ & $\begin{array}{l}189 \\
166 \\
192\end{array}$ & $\begin{array}{l}70 \\
69 \\
72\end{array}$ & $\begin{array}{l}.37 \\
.42 \\
.38\end{array}$ & $\begin{array}{l}148 \\
148 \\
148\end{array}$ & $\begin{array}{l}1.70 \\
1.14 \\
1.50\end{array}$ & $\begin{array}{r}227 \\
69 \\
114\end{array}$ & $\begin{array}{l}10.37 \\
10.21 \\
10.66\end{array}$ & $\begin{array}{l}97.8 \\
99.3 \\
98.9\end{array}$ & $\begin{array}{l}63 \\
72 \\
65\end{array}$ & \\
\hline 8 & $\begin{array}{l}\text { Control } \\
\text { Fistula } \\
\text { Recovery }\end{array}$ & $\begin{array}{l}174 \\
146 \\
178\end{array}$ & $\begin{array}{l}70 \\
69 \\
67\end{array}$ & $\begin{array}{l}.40 \\
.47 \\
.38\end{array}$ & $\begin{array}{l}146 \\
146 \\
146\end{array}$ & $\begin{array}{l}1.02 \\
0.94 \\
1.00\end{array}$ & $\begin{array}{l}48 \\
13 \\
30\end{array}$ & $\begin{array}{r}10.22 \\
10.08 \\
9.78\end{array}$ & $\begin{array}{l}99.5 \\
99.9 \\
99.7\end{array}$ & $\begin{array}{l}110 \\
127 \\
101\end{array}$ & $\begin{array}{l}2.2 \\
2.6 \\
1.7\end{array}$ \\
\hline 9 & $\begin{array}{l}\text { Control } \\
\text { Fistula } \\
\text { Recovery }\end{array}$ & $\begin{array}{l}204 \\
176 \\
208\end{array}$ & $\begin{array}{l}61 \\
58 \\
61\end{array}$ & $\begin{array}{l}.30 \\
.33 \\
.29\end{array}$ & $\begin{array}{l}147 \\
147 \\
147\end{array}$ & $\begin{array}{l}0.90 \\
0.78 \\
1.58\end{array}$ & $\begin{array}{r}24 \\
4 \\
53\end{array}$ & $\begin{array}{l}8.97 \\
8.53 \\
8.97\end{array}$ & $\begin{array}{r}99.7 \\
100.0 \\
99.4\end{array}$ & $\begin{array}{l}71 \\
88 \\
62\end{array}$ & $\begin{array}{l}2.4 \\
4.1 \\
2.3\end{array}$ \\
\hline 10 & $\begin{array}{l}\text { Control } \\
\text { Fistula } \\
\text { Recovery }\end{array}$ & $\begin{array}{l}197 \\
170 \\
195\end{array}$ & $\begin{array}{l}58 \\
56 \\
58\end{array}$ & $\begin{array}{l}.29 \\
.33 \\
.30\end{array}$ & $\begin{array}{l}147 \\
147 \\
147\end{array}$ & $\begin{array}{l}0.70 \\
0.71 \\
0.65\end{array}$ & $\begin{array}{r}54 \\
8 \\
21\end{array}$ & $\begin{array}{l}8.53 \\
8.24 \\
8.53\end{array}$ & $\begin{array}{l}99.4 \\
99.9 \\
99.8\end{array}$ & $\begin{array}{l}36 \\
47 \\
30\end{array}$ & $\begin{array}{l}1.4 \\
2.8 \\
1.6\end{array}$ \\
\hline
\end{tabular}

* The figures given in each experiment for RPF, GFR, FF, plasma sodium, urine volume, amount of sodium excreted, amount of sodium filtered, percentage of filtered sodium reabsorbed by the tubules, during the control period, during the patency of the fistula, and during the recovery period represent the average of the two values obtained during the two control periods, the two experimental periods, and the two recovery periods.

$\uparrow$ Filtered Na $=$ Plasma Na XGFR. Donnan Factor not applied. 


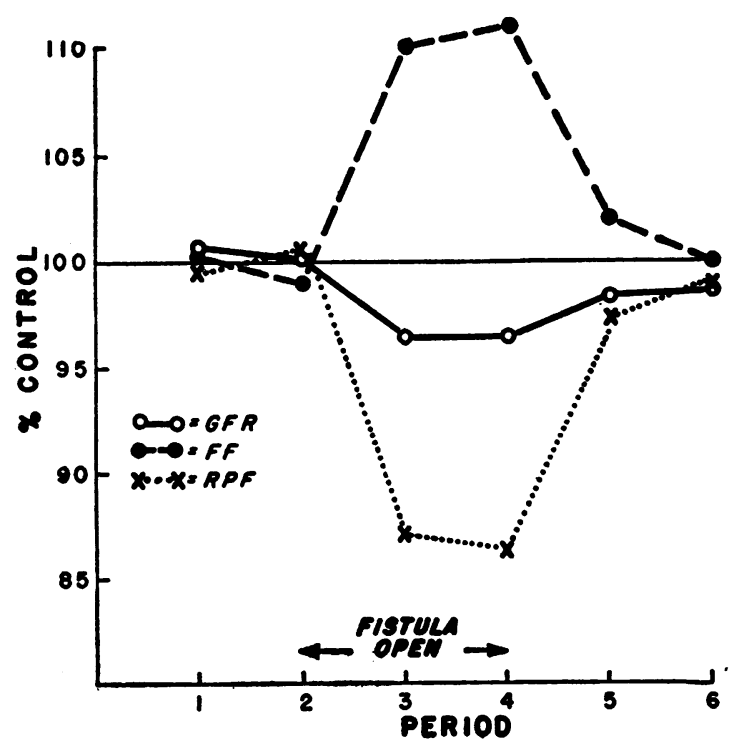

Fig. 1. Figure Illustrating the Efrect of Acute Arteriovenous Fistulae on RPF, GFR, ANd FF

Each value represents the average of the data obtained in all 10 experiments and is expressed in terms of per cent of the average control value.

fall was $24 \mathrm{~mm}$. of mercury. Within 3 to $10 \mathrm{~min}$ utes, the blood pressure progressively rose to its control level (experiment 3 ) or within the range of its control level, i.e., $2 \mathrm{~mm}$. of mercury above control level in experiments 4 and 5 , and 4, 2, 2, 6,3 , and $3 \mathrm{~mm}$. below control level in experiments $1,2,7,8,9$, and 10 , respectively. In only one experiment (experiment 6 ) did the blood pressure remain approximately $30 \mathrm{~mm}$. below its control level.

In all experiments the renal plasma flow fell during the patency of the fistula and returned to or toward its control level after the fistula was closed. The renal plasma flow fell 7 to 19 per cent of its control value and the average decrease amounted to 14 per cent of the average control value. The glomerular filtration rate decreased little or not at all, the maximal, minimal and average fall being 8,0 , and 3 per cent, respectively. Accordingly, the filtration fraction invariably rose. The amount of water, sodium, and chloride excreted fell during the patency of the fistula and the decrease of the urine volume was less marked than that of the amount of sodium and chloride excreted. In one experiment (experiment 10), the amount of urine excreted did not fall during the patency of the fistula although there was a diminution in the amount of sodium excreted. Upon closure of the fistula, the excretion of water, sodium, and chloride returned to, toward, or above the control levels. In experiments 8,9 , and 10 , in which the cardiac output was measured, the fistula increased the output 18, 70, and 104 per cent, respectively. In the last five experiments the mean venous pressure measured in the inferior vena cava at the level of the renal veins rose by 9 to $17 \mathrm{~mm}$. of water during the patency of the fistula.

Since the renal plasma flow decreased in all experiments and the mean aortic blood pressure did not change significantly except in one experiment, it can be concluded that the fistula decreased the renal plasma flow by inducing an increase in the vascular resistance of the kidneys. The slight decrease in the glomerular filtration rate observed in most experiments seems to indicate that the opening of the fistula induced constriction of the afferent glomerular arteriole at least in some experiments. However, since the filtration fraction rose, it follows that the resistance increased more in the postglomerular segment than in the preglo-

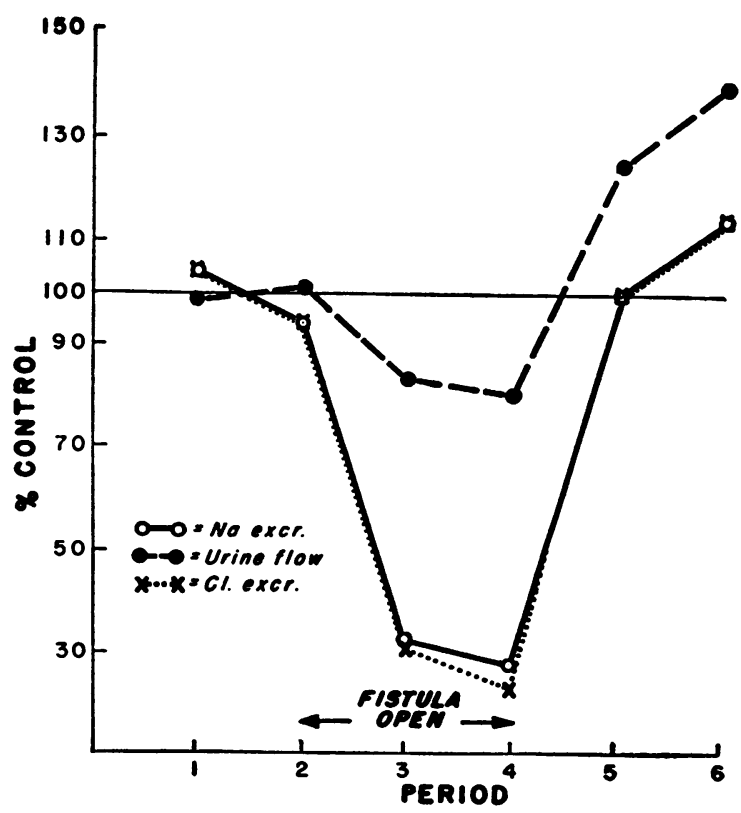

Fig. 2. Figure Illustrating the Emfect of Acute Arteriovenous Fistulae on the Urine Flow and the Amounts of Sodrum and Chloride Excretred

Each value represents the average of the data obtained in all 10 experiments and is expressed in terms of per cent of the average control value. 
merular segment of the renal vascular bed. It is improbable that the increase of the renal venous pressure observed was sufficient to account for the rise in the renal peripheral resistance (9).

The decrease in sodium excretion induced by opening the arteriovenous fistula was accompanied by an increase in the percentage of filtered sodium reabsorbed by the tubules in all 10 experiments. Similarly the increase in sodium excretion produced by closing the fistula was associated with a decrease in the percentage of filtered sodium reabsorbed in all 10 experiments. A similar correlation between the changes in sodium excretion produced by opening and closing the fistula and the changes in the amount of sodium filtered was also present in most experiments. Only once upon opening the fistula (experiment 3 ), there occurred an increase in the sodium excretion while the amount of filtered sodium increased and twice upon closing the fistula (experiments 7 and 8) the sodium excretion rose while the amount of filtered sodium decreased. With such data, an interpretation of the respective role of filtration and reabsorption in the phenomena observed is obviously hazardous but it would seem more likely that opening an arteriovenous fistula decreased the excretion of sodium by raising the percentage of filtered sodium reabsorbed by the tubules rather than by lowering the amount of sodium filtered, although both mechanisms may be present. It would be equally difficult to attempt to evaluate the relative importance of filtration and reabsorption in the decrease of water excretion produced by opening an arteriovenous fistula. The disparity between the degree of decrease in urine flow and the amount of sodium excreted suggests that the fistula may alter either the tubular transport of other osmotically active substances or the active reabsorption of water. Parenthetically, the patency of the fistula did not modify the excretion of potassium in the four experiments of the ten in which it was studied. Since the plasma level of potassium remained unchanged and the filtration rate fell, this would imply either that the reabsorption of potassium was decreased while the fistula was open, or that, as has been suggested by Berliner, Kennedy, and Hilton (10), such a constancy of the amount of potassium excreted in the face of changes in the amount of potassium filtered is due to the secretion of a constant amount of potassium by the tubules into a tubular fluid essentially free of this cation.

It is obvious that the decrease in sodium and water excretion produced by an acute arteriovenous fistula could lead to the retention of an important quantity of sodium and water if such a fistula were kept patent for a long enough period of time. This mechanism might well contribute to the increase in the extracellular fluid volume which is generally acknowledged to occur in patients and animals with a chronic arteriovenous fistula of some size. However, it would be hazardous to conclude from these experiments that the effect of the fistula on the renal excretion of sodium and water persists long enough to constitute an adequate explanation of the effect of such a fistula on the extracellular fluid volume. Furthermore, the retention of sodium and water could not continue indefinitely. In this respect, one might postulate that once the blood volume had increased sufficiently to bring the blood flow into the normal capillary bed to its pre-fistula level, the stimulus for vasoconstriction would be removed (1), the renal functions would revert to pre-fistula levels, and consequently a normal balance of sodium and water would be reestablished. The observations on the acute effect of opening an arteriovenous fistula on water and sodium excretion are in agreement with the results of Epstein, Post, and McDowell (3) who showed that the closure of a chronic arteriovenous fistula in humans results in a sudden diuresis of sodium and water. In their study, however, the occlusion of such a chronic shunt did not increase the renal plasma flow, whereas in the present experiments the opening of an acute shunt always results in a decrease of the renal plasma flow. The apparent difference between the mechanism by which, in the dog, the kidneys retain sodium and water when an acute arteriovenous fistula is opened and the mechanism by which, in humans, the kidneys eliminate an excess of sodium and water when a chronic arteriovenous fistula is closed, may represent a species difference. This discrepancy also suggests the possibility that the retention of sodium and water through a decrease in RPF and GFR may be only a temporary mechanism. Indeed it may well be that the increase in sodium reabsorption by the tubules, which seems to be partially responsible for the conservation of 
sodium in these acute experiments, becomes the main and perhaps the only mechanisms in longer experiments. If such is the case, one would expect that, as reported by Epstein, Post, and McDowell (3), the closing of a chronic fistula would result in sodium diuresis without affecting the renal plasma flow. For purely hemodynamic reasons, however, the absence of any change in renal plasma flow upon closing a chronic fistula is somewhat unexpected.

\section{SUMMARY AND CONCLUSIONS}

In the anesthetized dog, an acute arteriovenous fistula may lower the renal plasma flow by inducing renal vasoconstriction, reduce the glomerular filtration rate and decrease the amount of sodium, water, and chloride excreted. The mechanism of these effects as well as the possible role of the kidneys in the adaptation of the organism to the presence of an arteriovenous fistula are discussed.

\section{REFERENCES}

1. Frank, C. W., Wang, H., Lammerant, J., Miller, R., and Wégria, R., An experimental study of the immediate hemodynamic adjustments to acute arteriovenous fistulae of various sizes. J. Clin. Invest., 1955, 34, 722.

2. Lillehei, C. W., Bobb, J. R. R., and Visscher, M. B., Effect of arteriovenous fistulas upon pulmonary arterial pressure, cardiac index, blood volume, and the extracellular fluid space. Proceedings of the Forum Sessions Thirty-sixth Clinical Congress of the American College of Surgeons, 1950. Philadelphia, W. B. Saunders Co., 1951, p. 275.

3. Epstein, F. H., Post, R. S., and McDowell, M., The effect of an arteriovenous fistula on renal hemodynamics and electrolyte excretion. J. Clin. Invest., 1953, 32, 233.

4. Volhard, J. Z., Die anwendung des Schwefel cyanammoniums in der Mafsanalyse. Ann. d. Chem., $1878,190,1$.

5. Kennedy, T. J., Jr., Hilton, J. G., and Berliner, R. W., Comparison of inulin and creatinine clearance in the normal dog. Am. J. Physiol., 1952, 171, 164.

6. Smith, H. W., Finkelstein, N., Aliminosa, L., Crawford, B., and Graber, M., The renal clearances of substituted hippuric acid derivatives and other aromatic acids in dog and man. J. Clin. Invest., 1945, 24, 388.

7. Scholander, P. F., Analyzer for accurate estimation of respiratory gases in one-half cubic centimeter samples. J. Biol. Chem., 1947, 167, 235.

8. Van Slyke, D. D., and Neill, J. M., The determination of gases in blood and other solutions by vacuum extraction and manometric measurement. VII. Determination of oxygen in blood. J. Biol. Chem., 1924, 61, 554.

9. Blake, W. D., Wégria, R., Keating, R. P., and Ward, H. P., Effect of increased renal venous pressure on renal function. Am. J. Physiol., 1949, 157, 1.

10. Berliner, R. W., Kennedy, T. J., Jr., and Hilton, J. G., Renal mechanisms for excretion of potassium. Am. J. Physiol., 1950, 162, 348. 